\title{
PENGARUH PENGGUNAAN DRIED DISTILLERS GRAIN WITH SOLUBLE (DDGS) PADA RANSUM BERENERGI RENDAH TERHADAP KARKAS, LEMAK ABDOMINAL, DAN HATI AYAM BROILER
}

\section{THE EFFECT OF USING DRIED DISTILLERS GRAIN WITH SOLUBLE (DDGS) WITH LOW ENERGY DIET ON CARCASS, ABDOMEN FAT AND LIVER OF BROILER}

\author{
Edwin Indarto*, Jamhari, Fatimah Zahra, Zuprizal, dan Kustantinah \\ Fakultas Peternakan Universitas Gadjah Mada, Jl. Fauna No. 3, Bulaksumur, Yogyakarta, 55281
}

\section{INTISARI}

\begin{abstract}
Penelitian bertujuan untuk mengetahui pengaruh penggunaan Dried Distillers Grain with Soluble (DDGS) pada pakan dengan kandungan energi yang rendah terhadap berat dan persentase karkas, serta lemak abdominal dan hati ayam broiler. Penelitian menggunakan DOC broiler strain Lohmann sebanyak 125 ekor. Ayam broiler dikelompokkan ke dalam 5 level perlakuan dan dibagi menjadi 25 kandang dengan 5 replikasi yang masing-masing kandang terdiri dari 5 ekor. Level DDGS yang diberikan adalah 0, 20, 30, 40, dan 50\% dari total pakan. Penggunaan DDGS dilakukan dari umur 7 hari hingga umur 35 hari. Setelah umur 35 hari, dilakukan penimbangan berat potong dan pemotongan pada 25 ekor ayam broiler, kemudian penimbangan berat karkas, lemak abdominal, dan hati, serta perhitungan persentasenya. Penelitian menggunakan Rancangan Acak Lengkap pola searah (Completely Randomized Design). Apabila terjadi perbedaan yang nyata, analisis dilanjutkan dengan uji Duncan `s New Multiple Range Test (DMRT). Hasil penelitian menunjukkan bahwa penggunaan DDGS berpengaruh nyata terhadap berat dan persentase karkas, berat dan persentase lemak abdominal, dan berat hati. Berat karkas yang diperoleh dari masing-masing level berturut-turut adalah $625,40 \pm 55,38,608,60 \pm 55,61,568,20 \pm 123,87,422,80 \pm 55,97$ dan 401,80 $\pm 47,53 \mathrm{~g}$, dengan persentase karkas $61,79 \pm 1,83$, $61,70 \pm 2,78,60,17 \pm 2,57,57,19 \pm 2,22$ dan $56,68 \pm 3,61 \%$, berat lemak abdominal 15,60 $\pm 3,28,15,00 \pm 4,00,13,20 \pm 5,63$,

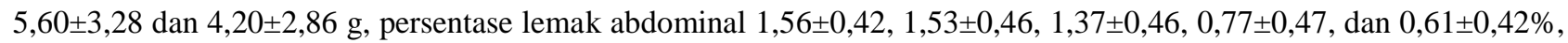

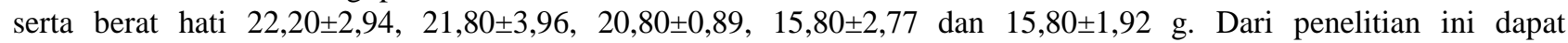
disimpulkan bahwa penggunaan DDGS hingga level 30\% tidak menaikkan atau menurunkan berat karkas dan hati, tetapi penggunaan level $40 \%$ dapat menurunkan berat dan persentase karkas yang diikuti dengan penurunan lemak abdominal dan hati ayam broiler.
\end{abstract}

(Kata kunci: Dried Distillers Grain with Soluble, Ayam broiler, Karkas, Lemak abdominal, Hati)

\begin{abstract}
The experiment was conducted to find out the effect of Dried Distillers Grain with Soluble (DDGS) with low energy diet on carcass, abdomen fat and liver of broiler throughout 35 days growing period. This experiment was conducted using 125 had of day old chick. The birds were randomly devided into five dietary treatments. Each dietary treatment was assigned to five replicate pens containing five chicks. The diets contained 0, 20, 30, 40 and 50\% DDGS. At 35-days old, 25 birds were weighed and slaughtered, then the carcass, abdomen fat and liver were weighed. The data were analyzed by Oneway Anova. The Duncan's New Multiple Range Test (DMRT) were used to analyze the differences between means. There were significant effects of DDGS level on carcass weight and percentage, abdomen fat and percentage, and liver weight. Carcass weight of broiler chicken of $R 0, R 20, R 30, R 40$ and $R 50$ were $625.40 \pm 55.38,608.60 \pm 55.61,568.20 \pm 123.87,422.80 \pm 55.97$, and $401.80 \pm 47.53 \mathrm{~g}$, carcass percentage were $61.79 \pm 1.83,61.70 \pm 2.78,60.17 \pm 2.57,57.19 \pm 2.22$, and $56.68 \pm 3.61 \%$, abdomen fat weight were $15.60 \pm 3.28,15.00 \pm 4.00$, $13.20 \pm 5.63,5.60 \pm 3.28$, and $4.20 \pm 2.86 \mathrm{~g}$, abdomen fat percentage were $1.56 \pm 0.42,1.53 \pm 0.46,1.37 \pm 0.46,0.77 \pm 0.47$, and $0.61 \pm 0.42 \%$, and liver weight were $22.20 \pm 2.94,21.80 \pm 3.96,20.80 \pm 0.89,15.80 \pm 2.77$, and $15.80 \pm 1.92 \mathrm{~g}$, respectively. It is concluded that the use of DDGS up to $30 \%$ could maintain the carcass, but the use of $40 \%$ DDGS decreased carcass weight and percentage, as well as the abdomen fat and liver.
\end{abstract}

(Key words: Dried Distillers Grain with Soluble, Broiler chicken, Carcass, Abdomen fat, Liver)

\footnotetext{
* Korespondensi (corresponding author):

Telp. +62811263651

E-mail: edwin_indart@yahoo.com
} 


\section{Pendahuluan}

Seiring dengan meningkatnya populasi manusia di dunia, maka persaingan penggunaan jagung sebagai bahan pangan dan bahan pakan semakin besar yang menyebabkan harga jagung naik. Jagung merupakan bahan baku utama dalam pemeliharaan ternak unggas, yaitu 50 sampai $60 \%$. Biaya yang dikeluarkan untuk pakan merupakan bagian yang paling besar yang mempengaruhi perkembangan peternakan unggas, yaitu dapat mencapai $70 \%$ dari total biaya produksi (Tangendjaja, 2007). Total pakan yang diproduksi dalam industri pakan global adalah 700 juta ton dan sebanyak 55\% dari total biaya produksi adalah untuk bahan baku sumber energi (Anonimus, 2008), sehingga adanya perubahan kecil dari harga bijian sumber energi akan berpengaruh banyak pada harga pakan. Ketersediaan dan harga jagung yang tidak konsisten ini memacu dunia peternakan untuk menciptakan suatu alternatif bahan pakan, salah satunya dengan produk samping dari fermentasi jagung yang disebut Dried Distillers Grain with Soluble (DDGS).

DDGS merupakan produk samping dari industri etanol. Penggunaan DDGS meningkat seiring dengan pertumbuhan industri bioetanol di Amerika Serikat. Produksi jagung di wilayah Amerika Serikat yang mencapai 213 juta ton pada tahun 2009 dan sebanyak 104 juta ton telah dimanfaatkan sebagai etanol (USDA, 2009). Banyaknya jumlah jagung yang digunakan sebagai etanol itu, akan menghasilkan produk samping yang dapat mencemari lingkungan apabila tidak digunakan kembali. Penanganan produk samping dapat dilakukan dengan memanfaatkannya sebagai bahan pakan ternak. Proses produksi etanol akan menghasilkan bahan bakar (etanol) dan butiran yang disebut DDGS. Butiran tersebut telah mengalami fermentasi dan pengeringan, sehingga didapatkan hasil nutrien yang baik untuk dijadikan sebagai bahan pakan ternak.

DDGS dapat digunakan sebagai bahan pakan sumber protein yang potensial untuk dijadikan pakan ternak. Kandungan protein DDGS adalah 26,16\% (Wang et al., 2007). Rerata energi yang termetabolis dari DDGS adalah $2.865 \mathrm{kcal} / \mathrm{kg}$ (Noll et al., 2003). Proses enzimatis oleh enzim bakteri fermentor dalam aktivitas fermentasi jagung menjadikan bahan ini juga kaya dengan phosphor available. Menurut Wang et al. (2008), kandungan phosphor available ( $\mathrm{P}$ available) dalam DDGS adalah $0,85 \%$.

Laju pertumbuhan dan kualitas daging sangat dipengaruhi oleh nutrien dalam pakan. Perbedaan komposisi nutrien bahan pakan dalam campuran pakan akan mempengaruhi kualitas pakan, yang akan menyebabkan konsumsi pakan serta absorbsi di dalam tubuh juga berbeda. Jumlah nutrien yang diabsorbsi akan berpengaruh terhadap metabolisme tubuh dan performans ternak. Laju pertumbuhan terlihat pada berat akhir, karkas serta organ tubuh yang lain. Kualitas karkas dipengaruhi oleh komposisi nutrisinya, antara lain lemak. Lemak daging diperlukan dalam jumlah tertentu, tetapi jika kandungan lemak berlebihan akan mempunyai pengaruh negatif terhadap konsumen. Pembatasan kandungan energi dalam pakan dapat digunakan untuk menurunkan pembentukan lemak abdominal ayam broiler. Penelitian ini bertujuan untuk mengetahui pengaruh penggunaan DDGS dalam pakan dengan kandungan energi yang rendah terhadap berat dan persentase karkas, lemak abdominal dan hati ayam broiler.

\section{Materi dan Metode}

\section{Waktu dan tempat penelitian}

Penelitian dilaksanakan pada bulan Oktober sampai dengan Desember 2010 dengan menggunakan lokasi kandang Laboratorium Ilmu Makanan Ternak Fakultas Peternakan, Universitas Gadjah Mada.

\section{Materi penelitian}

Materi yang digunakan dalam penelitian adalah ayam broiler strain Lohmann unsexed, produksi Multibreeder Adirama Indonesia sebanyak 125 ekor yang dipelihara selama 35 hari. Kandang yang digunakan adalah kandang dengan sistem litter dengan ukuran $0,5 \times 1 \mathrm{~m}^{2}$ sebanyak 25 kandang yang dilengkapi dengan sekam sebagai alas kandang. Alat yang digunakan pada penelitian adalah seperangkat kandang ayam dengan sistem litter, tempat pakan, tempat minum, cable tie, timbangan analitik camry, lampu 40 watt.

\section{Pakan}

Pakan yang digunakan dalam penelitian adalah pakan komersial, jagung kuning giling, bungkil kedelai, bekatul, tepung ikan, DDGS, premix, garam, limestone, dan filler. Komposisi nutrien bahan pakan disajikan pada Tabel 1 .

\section{Persiapan}

Persiapan yang dilakukan di kandang adalah merangkai kandang dengan sistem litter, meletakkan sekam sebagai alas, dan melakukan fumigasi dengan menggunakan desinfektan (formaldehid) seminggu sebelum chick in.

\section{Pemeliharaan}

DOC sebanyak 125 ekor dipelihara selama 35 hari dengan sistem litter. Pemeliharaan dilakukan pada 25 unit kandang yang masing-masing 
Tabel 1. Kandungan nutrien bahan pakan (nutrient content of feedstuffs)

\begin{tabular}{|c|c|c|c|c|c|c|c|c|c|}
\hline Bahan pakan (feedstuffs) & $\begin{array}{l}\mathrm{PK}(\mathrm{CP}) \\
(\%)\end{array}$ & $\begin{array}{c}\mathrm{ME} \\
(\mathrm{kcal} / \mathrm{kg})\end{array}$ & $\begin{array}{c}\text { SK (CF) } \\
(\%)\end{array}$ & $\begin{array}{l}\text { LK (EE) } \\
(\%)\end{array}$ & $\begin{array}{l}\mathrm{Ca} \\
(\%)\end{array}$ & $\begin{aligned} \mathrm{P} \text { av } \\
(\%)\end{aligned}$ & $\begin{array}{c}\text { Lysin } \\
(\%)\end{array}$ & $\begin{array}{c}\text { Methionine } \\
(\%)\end{array}$ & $\begin{array}{l}\text { Tryptofan } \\
(\%)\end{array}$ \\
\hline $\begin{array}{l}\text { Jagung kuning giling } \\
(\text { ground yellow corn) }\end{array}$ & 8,50 & 3.350 & 2,20 & 3,80 & 0,02 & 0,08 & 0,26 & 0,18 & 0,06 \\
\hline DDGS $^{1}$ & 27,40 & 2.480 & 9,10 & 9,00 & 0,17 & 0,39 & 0,75 & 0,60 & 0,19 \\
\hline Tepung ikan (fish meal) ${ }^{1}$ & 64,20 & 2.580 & 1,00 & 5,00 & 3,73 & 2,20 & 5,07 & 1,95 & 0,78 \\
\hline Bekatul (wheat bran) ${ }^{1}$ & 12,90 & 2.980 & 6,00 & 13,00 & 0,07 & 0,22 & 0,59 & 0,26 & 0,12 \\
\hline $\begin{array}{l}\text { Bungkil kedelai (soybean } \\
\text { meal) }\end{array}$ & 44,00 & 2.230 & 7,00 & 0,80 & 0,29 & 0,27 & 2,69 & 0,62 & 0,74 \\
\hline $\mathrm{NaCl}^{1}$ & 0,00 & 0,00 & 0,00 & 0,00 & 0,00 & 0,00 & 0,00 & 0,00 & 0,00 \\
\hline Mineral B12 & 0,00 & 0,00 & 0,00 & 0,00 & 49,00 & 14,00 & 0,00 & 0,00 & 0,00 \\
\hline Limestone $^{2}$ & 0,00 & 0,00 & 0,00 & 0,00 & 34,00 & 0,02 & 0,00 & 0,00 & 0,00 \\
\hline Filler & 0,00 & 0,00 & 0,00 & 0,00 & 0,00 & 0,00 & 0,00 & 0,00 & 0,00 \\
\hline
\end{tabular}

Berdasarkan NRC (1994) (based on NRC (1994))

${ }^{2}$ Berdasarkan Hartadi et al. (2005) (based on Hartadi et al. (2005))

PK (CP): protein kasar (crude protein)

ME: metabolizable energy

SK (CF): serat kasar (crude fiber)

LK (EE): lemak kasar (extract ether)

Ca: calsium

$\mathrm{P}$ av: $\mathrm{P}$ available

berukuran $0,5 \times 1 \mathrm{~m}$ dengan menggunakan lampu 40 watt. Perlakuan yang dilakukan adalah dengan pemberian DDGS pada ransum dengan kandungan energi pakan rendah sebanyak $0 \%$ (R 0 , sebagai kontrol), 20\% (R 20), 30\% (R 30), 40\% (R 40), dan $50 \%$ (R 50) dari total jumlah pakan yang diberikan pada setiap perlakuan. Replikasi masing-masing perlakuan sebanyak 5 kali, setiap replikasi menggunakan 5 ekor ayam. Pengelompokan kandang dan DOC ke dalam kandang dilakukan secara random, yaitu dengan cara pengundian.

Sistem pemberian pakan dilakukan secara $a d$ libitum. Penimbangan sisa pakan dilakukan setiap pagi. Pakan pakan komersial diberikan pada hari pertama hingga hari ketujuh, kemudian dilanjutkan dengan pemberian pakan yang mengandung DDGS hingga hari ke 35. Perhitungan konsumsi pakan dilakukan setiap pagi hari saat pemberian pakan. Pencampuran pakan dilakukan setiap minggu. Komposisi pakan disajikan pada Tabel 2. Penimbangan terhadap masing-masing ayam dilakukan setiap minggu. Vaksinasi yang dilakukan adalah ND pada hari ke tujuh dan gumboro pada hari ke 12.

\section{Proses pemotongan}

Pemotongan dilakukan setelah pemeliharaan selama 35 hari. Ayam broiler diambil secara random pada 25 kandang masing-masing satu ekor (setiap perlakuan diambil 5 replikasi). Pengambilan secara random ini dilakukan dengan cara pengundian dari setiap kandang dengan identifikasi masingmasing individu dalam kandang. Ayam kemudian dipotong dan diproses menjadi karkas. Pemotongan dilakukan dengan memotong bagian arteri carotis, vena jugularis, dan esophagus (Soeparno, 2005).

\section{Pengambilan data}

Penimbangan dan pengambilan data dilakukan sebelum dan setelah pemotongan. Data yang diambil sebelum pemotongan adalah berat potong, sedangkan data yang diambil setelah pemotongan meliputi karkas, lemak abdominal, dan hati.

Karkas. Berat karkas ditimbang dengan mengurangi darah, bulu, kaki (dari metatarsus), kepala, dan semua organ dalam (kecuali ginjal dan paru-paru). Persentase karkas diperoleh dari berat karkas dibagi berat potong dikalikan $100 \%$ (Soeparno, 2005).

Lemak abdominal. Lemak abdominal didapat dari lemak yang terdapat pada sekeliling gizard dan lapisan yang menempel antara otot abdominal serta usus (Setiawan dan Sujana, 2009). Persentase lemak abdominal diperoleh dari berat lemak abdominal dibagi berat potong dikalikan $100 \%$.

Hati. Berat hati diambil dengan menimbang hati. Perhitungan persentase hati diperoleh dari berat hati dibagi berat potong dikalikan $100 \%$.

\section{Analisis statistik}

Penelitian ini menggunakan Rancangan Acak Lengkap pola searah (Completely Randomized Design). Apabila terjadi perbedaan yang nyata dilanjutkan dengan uji Duncan's New Multiple Range Test (DMRT). 
Tabel 2. Komposisi pakan (feedstuffs composition)

\begin{tabular}{|c|c|c|c|c|c|}
\hline Bahan pakan (feedstuffs) & R0 & R20 & R30 & $\mathrm{R} 40$ & $\mathrm{R} 50$ \\
\hline Jagung kuning giling (ground yellow corn) & 33,70 & 33,70 & 33,70 & 33,70 & 33,70 \\
\hline DDGS & 0,00 & 20,00 & 30,00 & 40,00 & 50,00 \\
\hline Tepung ikan (fish meal) & 5,00 & 1,30 & 5,40 & 4,30 & 2,90 \\
\hline Bekatul (wheat bran) & 34,50 & 24,00 & 19,65 & 16,00 & 9,50 \\
\hline Bungkil kedelai (soybean meal) & 23,00 & 18,50 & 9,00 & 4,00 & 1,65 \\
\hline $\mathrm{NaCl}$ & 0,25 & 0,25 & 0,25 & 0,25 & 0,25 \\
\hline Mineral B12 & 0,50 & 0,50 & 0,50 & 0,50 & 0,50 \\
\hline Limestone & 1,35 & 1,75 & 1,50 & 1,25 & 1,50 \\
\hline Filler & 1,70 & 0,00 & 0,00 & 0,00 & 0,00 \\
\hline Total $(\%)$ & 100,00 & 100,00 & 100,00 & 100,00 & 100,00 \\
\hline \multicolumn{6}{|l|}{ Kandungan nutrien (nutrient composition) ${ }^{1}$} \\
\hline ME (kcal/kg) & $2.798,95$ & $2.786,24$ & $2.798,54$ & $2.797,89$ & $2.763,67$ \\
\hline PK $(\%)(C P(\%))$ & 20,64 & 20,42 & 21,05 & 20,40 & 20,38 \\
\hline $\mathrm{Ca}(\%)$ & 0,99 & 1,00 & 1,05 & 0,92 & 0,97 \\
\hline $\mathrm{P}$ av $(\%)$ & 0,35 & 0,31 & 0,40 & 0,39 & 0,38 \\
\hline $\operatorname{SK}(\%)(C F(\%))$ & 4,47 & 5,31 & 5,33 & 5,66 & 6,01 \\
\hline $\operatorname{LK}(\%)(E E(\%))$ & 6,20 & 6,41 & 6,87 & 7,20 & 7,17 \\
\hline Lisin (\%) (lysin (\%)) & 1,16 & 0,94 & 0,94 & 0,80 & 0,71 \\
\hline Metionin (\%) (methionine (\%)) & 0,39 & 0,38 & 0,45 & 0,45 & 0,45 \\
\hline Triptofan (\%) (tryptophan (\%)) & 0,27 & 0,23 & 0,21 & 0,17 & 0,16 \\
\hline
\end{tabular}

${ }^{\mathrm{T}}$ Perhitungan berdasarkan tabel komposisi bahan pakan (Hari Hartadi et al., 2005) (calculation based on the feedstuff composition table (Hari Hartadi et al., 2005)).

\section{Hasil dan Pembahasan}

\section{Konsumsi pakan dan pertambahan bobot badan}

Pertambahan berat badan dipengaruhi oleh konsumsi pakan (Tabel 3). Jika konsumsi pakan berkurang, maka konsumsi nutrien akan berkurang, sehingga absorbsi nutrien dalam tubuh juga mengalami penurunan, akibatnya kebutuhan ternak tidak terpenuhi dan performans ternak tidak maksimal. Kebutuhan nutrien yang dimaksud meliputi kebutuhan energi dan protein (terutama asam amino). Kandungan ME dalam pakan ayam broiler berkisar antara 2.763,67 sampai $2.798,95$ $\mathrm{kcal} / \mathrm{kg}$ dengan kandungan protein kasar 20,38 sampai 21,05\%. Menurut NRC (1994), kebutuhan energi sebesar $3.200 \mathrm{kcal} / \mathrm{kg}$ dan protein kasar sebanyak $21 \%$ dalam pakan dapat memenuhi kebutuhan ayam broiler. Kandungan ME dalam ransum yang diberikan rendah, sedangkan kandungan protein sesuai kebutuhan dengan perbandingan protein dan ME adalah 1:135. Pemberian pakan dengan kandungan energi yang rendah menyebabkan tidak semua bagian protein pakan dapat dicerna, karena energi yang masuk ke dalam tubuh lebih rendah, sehingga protein banyak yang terbuang melalui ekskreta.

\section{Karkas}

Hasil analisis variansi untuk berat karkas menunjukkan perbedaan yang nyata $(\mathrm{P}<0,05)$. Berat karkas disajikan pada Tabel 4.
Hasil penelitian menunjukkan bahwa penambahan DDGS memberikan pengaruh yang nyata terhadap berat karkas. Berat karkas R 0, R 20, R 30, R 40, dan R 50 berturut-turut adalah $625,40 \pm 55,38$, $608,60 \pm 55,61,568,20 \pm 123,87,422,80 \pm 55,97$, dan $401,80 \pm 47,53$ g. Penggunaan level DDGS hingga $30 \%$ dapat mempertahankan berat karkas, sedangkan dengan level penggunaan $40 \%$ menurunkan berat karkas. Penurunan berat karkas disebabkan oleh average daily gain (ADG) yang menurun (Tabel 4).

Peningkatan penggunaan level DDGS menyebabkan penurunan berat karkas mulai dari level penggunaan $40 \%$. Hal ini dipengaruhi kandungan asam amino dalam pakan yang berbeda, yaitu asam amino lisin. Semakin tinggi level perlakuan pakan, kandungan asam amino lisin semakin rendah, sehingga berat karkas yang diperoleh semakin menurun. Abun (2006), menyatakan bahwa kualitas protein pada dasarnya ditentukan oleh komposisi asam amino. Asam amino lisin adalah asam amino esensial pada unggas yang merupakan salah satu asam amino pembatas (Razeai et al., 2004), sedangkan asam amino pembatas pada unggas yang lain adalah metionin dan triptofan (Sitompul, 2004). Lisin adalah salah satu asam amino esensial dengan rumus molekul $\mathrm{C}_{6} \mathrm{H}_{14} \mathrm{O}_{2} \mathrm{~N}_{2}$ dan merupakan penyusun jaringan tubuh dengan persentase paling tinggi di antara asam amino yang lain. Lisin tidak stabil oleh pengaruh panas dalam suasana asam karena gugus aminonya lepas. Tingkat kecernaan 
Tabel 3. Konsumsi pakan dan pertambahan bobot badan ayam broiler yang diberi DDGS dari umur 8 sampai 35 hari (feed intake and body weight gain of broiler which were fed with DDGS at 8 to 35 days of age)

\begin{tabular}{ccc}
\hline \hline Perlakuan (treatment) & $\begin{array}{c}\text { Konsumsi pakan (g/ekor) (feed } \\
\text { intake }(\mathrm{g} / \text { head) })\end{array}$ & $\begin{array}{c}\text { Pertambahan bobot badan (g/ekor) (body } \\
\text { weight gain (g/head)) }\end{array}$ \\
\hline R 0 & $2.706,66 \pm 182,09^{\mathrm{b}}$ & $812,28 \pm 52,62^{\mathrm{d}}$ \\
R 10 & $2.615,42 \pm 271,12^{\mathrm{b}}$ & $803,88 \pm 25,03^{\mathrm{d}}$ \\
R 20 & $2.627,82 \pm 181,12^{\mathrm{b}}$ & $819,44 \pm 60,52^{\mathrm{d}}$ \\
R 30 & $2.640,87 \pm 157,78^{\mathrm{b}}$ & $695,32 \pm 122,92^{\mathrm{c}}$ \\
R 40 & $2.116,30 \pm 111,86^{\mathrm{a}}$ & $561,80 \pm 93,81^{\mathrm{b}}$ \\
R 50 & $1.957,26 \pm 191,23^{\mathrm{b}}$ & $424,08 \pm 51,72^{\mathrm{a}}$ \\
\hline
\end{tabular}

a,b,c,d Superskrip yang berbeda pada kolom yang sama menunjukkan perbedaan yang nyata $(\mathrm{P}<0,05)$ (different superscripts at the same column indicate significant differences $(P<0.05))$.

Tabel 4. Karkas ayam broiler yang diberi DDGS umur 35 hari (broiler carcass which were fed with DDGS age 35 days)

\begin{tabular}{ccc}
\hline \hline Perlakuan (treatment) & Berat karkas $(\mathrm{g})($ carcass weight $(g))$ & $\begin{array}{c}\text { Persentase karkas }(\%)(\text { carcass } \\
\text { percentage }(\%))\end{array}$ \\
\hline R 0 & $652,40 \pm 55,38^{\mathrm{b}}$ & $61,79 \pm 1,83^{\mathrm{b}}$ \\
R 20 & $608,60 \pm 55,61^{\mathrm{b}}$ & $61,70 \pm 2,78^{\mathrm{b}}$ \\
R 30 & $568,20 \pm 123,87^{\mathrm{b}}$ & $60,17 \pm 2,57^{\mathrm{ab}}$ \\
R 40 & $422,80 \pm 55,97^{\mathrm{a}}$ & $57,19 \pm 2,22^{\mathrm{a}}$ \\
R 50 & $401,80 \pm 47,53^{\mathrm{a}}$ & $56,68 \pm 3,61^{\mathrm{a}}$ \\
\hline
\end{tabular}

Superskrip yang berbeda pada kolom yang sama menunjukkan perbedaan yang nyata $(\mathrm{P}<0,05)$ (different superscripts at the same column indicate significant differences $(P<0.05))$.

lisin sangat tinggi dan digunakan untuk pertumbuhan serta pembentukan protein (Baker dan Han, 1993). Menurut Lumpkins dan Batal (2005), proses pengeringan pada pembuatan DDGS dilakukan pada suhu tinggi, mencapai $315^{\circ} \mathrm{C}$ dapat menurunkan ketersediaan asam amino.

Menurut Leclercq (1998), lisin dan asam amino yang mengandung sulfur merupakan faktor yang mempengaruhi komposisi karkas. Pemberian asam amino di atas kebutuhan dapat menghasilkan karkas yang optimal. Lisin berperan dalam proses pertumbuhan dan pembentukan protein tubuh. Razeai et al. (2004) menambahkan bahwa asam amino lisin diperlukan untuk menghasilkan produksi karkas yang lebih tinggi dengan berat badan yang optimal.

Kandungan asam amino lisin pada R 0, R 20, R 30, R 40, dan R 50 semakin menurun, yaitu 1,16, 0,94, 0,94, 0,80, dan 0,71\%. Menurut NRC (1994), kebutuhan lisin ayam broiler adalah $1,1 \%$. Kandungan lisin dalam pakan yang mengandung DDGS belum memenuhi kebutuhan. Ketidakseimbangan asam amino dalam pakan yang berbeda menyebabkan perbedaan konsumsi pakan, sehingga menyebabkan nutrien yang diabsorbsi tubuh tidak sama pada setiap level perlakuan. Kandungan protein kasar yang tinggi dengan asam amino yang seimbang dapat memenuhi kebutuhan tubuh. Defisiensi sebuah asam amino tunggal menyebab- kan segera berhentinya pertumbuhan dan kehilangan pertumbuhan rerata sebesar 6 sampai $7 \%$ dari berat badan per hari (Abun, 2006; Juju, 2004), sehingga performans yang dihasilkan menurun.

Selain kandungan lisin dalam pakan yang tidak terpenuhi, faktor lain yang mempengaruhi penurunan produksi karkas adalah serat kasar. Hal ini sesuai dengan penelitian Mahfudz (2006) yang menyatakan bahwa tingginya kandungan serat kasar pada pakan dapat berakibat unggas cepat kenyang dan konsumsi pakan menjadi terbatas. Shanin dan Azeem (2006) menambahkan bahwa karkas ayam yang diberi pakan dengan kandungan serat tinggi memiliki proporsi berat karkas yang lebih rendah daripada ayam yang diberi pakan dengan kandungan serat rendah.

Penggunaan DDGS juga berpengaruh nyata $(\mathrm{P}<0,05)$ terhadap persentase karkas. Persentase karkas disajikan pada Tabel 4. Persentase karkas R 0, R 20, R 30, R 40, dan R 50 berturut-turut adalah $61,79 \pm 1,83, \quad 61,70 \pm 2,78, \quad 60,17 \pm 2,57$, $57,19 \pm 2,22$ dan $56,68 \pm 3,61 \%$. Perbedaan yang nyata persentase karkas terlihat pada penggunaan level DDGS $40 \%$. Persentase karkas diperoleh dengan melakukan pembagian berat karkas dengan berat potong dikalikan 100\% (Wahyurinaningsih, 2001). Penurunan berat karkas dipengaruhi oleh berat karkas dan berat potong. 


\section{Lemak abdominal}

Hasil penelitian menunjukkan bahwa penggunaan DDGS memberikan pengaruh yang nyata terhadap berat lemak abdominal. Berat lemak abdominal disajikan pada Tabel 5. Berat lemak abdominal R 0, R 20, R 30, R 40, dan R 50 adalah $15,60 \pm 3,28, \quad 15,00 \pm 4,00,13,20 \pm 5,63,5,60 \pm 3,28$, dan $4,20 \pm 2,86$ g. Penurunan berat lemak abdominal diperoleh pada level penggunaan DDGS $40 \%$. Lemak abdominal didapat dari lemak yang terdapat pada sekeliling gizzard dan lapisan yang menempel antara otot abdominal serta usus (Setiawan dan Sujana, 2009).

Menurut Soeparno (2005), pengukuran lemak abdominal dapat digunakan sebagai indikator dari total lemak tubuh. Berat lemak abdominal cenderung meningkat seiring dengan pertambahan umur. Pada periode ternak awal, lemak yang disimpan dalam tubuh jumlahnya sedikit, namun pada pertumbuhan akhir proses pertumbuhan lemak akan berlangsung cepat dan lemak akan disimpan di bawah kulit, di sekitar organ dalam, antara lain empedal, usus, dan otot (Deaton et al., 1972 cit. Sulastri, 2003). Penimbunan lemak abdominal di dalam rongga perut akan berpengaruh terhadap berat karkas (Akiba, 1992).

Juju (2004) menyatakan bahwa akumulasi total lemak tubuh dan penyebarannya pada bagianbagian tubuh ayam pedaging dipengaruhi oleh pakan. Komposisi dalam pakan merupakan faktor yang mempengaruhi kandungan lemak tubuh. Pembentukan lemak tubuh pada ayam terjadi karena adanya kelebihan energi yang dikonsumsi. Energi yang digunakan tubuh umumnya berasal dari karbohidrat dan cadangan lemak. Sumber karbohidrat dalam tubuh mampu memproduksi lemak tubuh yang disimpan di sekeliling jeroan dan di bawah kulit (Setiawan dan Sujana, 2009).

Hasil penelitian menunjukkan bahwa penambahan DDGS menyebabkan penurunan berat lemak abdominal. Penurunan ini terjadi karena kandungan serat kasar dalam level perlakuan pakan berbeda. Semakin tinggi level perlakuan pakan, kandungan serat kasar meningkat. Selulosa dan hemiselulosa merupakan bagian dari karbohidrat tidak dapat dicerna unggas. Menurut Juju (2004), hal ini disebabkan karena unggas tidak memiliki enzim untuk memecah selulosa di dalam pencernaannya, sehingga serat kasar bersifat bulky (pengganjal kasar) yang tidak esensial pada pakan ayam. Digesti selulosa terjadi pada sekum unggas yang dibantu oleh mikroorganisme (Yuwanta, 2004), tetapi hasil pencernaan ini hanya sedikit yang dapat dimanfaatkan oleh tubuh kembali, karena akan segera dikeluarkan bersama ekskreta melalui kloaka.

Kandungan serat kasar dalam pakan $\mathrm{R} 0$, R 20, R 30, R 40, dan R 50 berturut-turut adalah 4,47, 5,31, 5,33, 5,66, dan 6,01\%. Menurut Rizal (2006), kandungan serat kasar dalam pakan ayam broiler dapat mencapai $6 \%$. Kandungan serat kasar dalam pakan sesuai dengan jumlah yang dapat dicerna oleh unggas. Penggunaan serat kasar dalam jumlah yang lebih tinggi dalam pakan akan bersifat bulky yang menyebabkan saluran pencernaan penuh berisi pakan, sehingga ayam akan cepat merasa kenyang karena konsumsi serat kasar, tetapi kebutuhan energi belum tercukupi (Zuprizal dan Kamal, 2005). Semakin tinggi kandungan serat kasar dalam pakan menyebabkan konsumsi pakan menurun. Konsumsi nutrien yang rendah belum dapat memenuhi kebutuhan ayam, karena nutrien yang diabsorpsi rendah, sehingga pertumbuhan tidak maksimal.

Selulosa dalam saluran pencernaan cenderung mengurangi pergerakan makanan (Anggorodi, 1995), sehingga lemak abdominal akan menurun dengan pemberian kandungan serat kasar yang tinggi dalam pakannya, sesuai dengan pernyataan Wahyurinaningsih (2001). Selain itu, perbedaan kandungan asam amino lisin merupakan penyebab dari penurunan berat dan persentase lemak abdominal. Hal ini sesuai dengan pernyataan Indarsih (2009), bahwa pakan dengan kandungan asam amino lisin yang lebih tinggi akan menghasilkan lemak yang lebih rendah, karena ternak

Tabel 5. Lemak abdominal ayam broiler yang diberi DDGS umur 35 hari (abdominal fat of broiler which were fed with DDGS at 35 days of age)

\begin{tabular}{ccc}
\hline \hline Perlakuan (treatment) & $\begin{array}{c}\text { Berat lemak abdominal (g) (abdominal } \\
\text { fat weight }(\mathrm{g}))\end{array}$ & $\begin{array}{c}\text { Persentase lemak abdominal (\%) } \\
\text { (abdominal fat percentage (\%)) }\end{array}$ \\
\hline R 0 & $15,60 \pm 3,28^{\mathrm{b}}$ & $1,56 \pm 0,42^{\mathrm{b}}$ \\
R 20 & $15,00 \pm 4,00^{\mathrm{b}}$ & $1,53 \pm 0,46^{\mathrm{b}}$ \\
R 30 & $13,20 \pm 5,63^{\mathrm{b}}$ & $1,37 \pm 0,46^{\mathrm{b}}$ \\
R 40 & $5,60 \pm 3,28^{\mathrm{a}}$ & $0,77 \pm 0,47^{\mathrm{a}}$ \\
R 50 & $4,20 \pm 2,86^{\mathrm{a}}$ & $0,61 \pm 0,42^{\mathrm{a}}$ \\
\hline
\end{tabular}

${ }^{\mathrm{a}, \mathrm{b}}$ Superskrip yang berbeda pada kolom yang sama menunjukkan perbedaan yang nyata $(\mathrm{P}<0,05)($ different superscripts at the same column indicate significant differences $(P<0.05))$. 
yang diberi pakan dengan kandungan lisin yang lebih tinggi akan menghasilkan pertumbuhan yang lebih maksimal.

Penurunan berat lemak abdominal ayam broiler yang diberi DDGS juga diikuti dengan penurunan persentasenya. Persentase lemak abdominal disajikan pada Tabel 5 .

Berdasarkan hasil penelitian, persentase lemak abdominal yang diperoleh dari R $0, \mathrm{R} 20, \mathrm{R} 30$, $\mathrm{R} 40$, dan R 50 berturut-turut adalah 1,56 $\pm 0,42$, $1,53 \pm 0,46,1,37 \pm 0,46,0,77 \pm 0,47$, dan $0,61 \pm 0,42 \%$ berbeda nyata. Penurunan persentase lemak abdominal secara nyata didapatkan pada $\mathrm{R} 40$. Persentase lemak abdominal diperoleh dari berat lemak abdominal dibagi berat potong dikalikan $100 \%$. Persentase lemak abdominal dipengaruhi oleh berat lemak abdominal dan berat potong.

\section{Hati}

Hasil penelitian menunjukkan bahwa penggunaan DDGS memberikan pengaruh yang nyata terhadap berat hati $(\mathrm{P}<0,05)$. Berat hati perlakuan $\mathrm{R}$

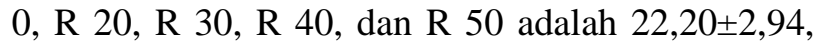

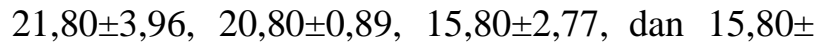
1,92 g (Tabel 6). Penurunan berat hati terjadi pada level penggunaan DDGS $40 \%$. Berat hati dipengaruhi oleh aktivitasnya, yaitu dalam proses metabolisme nutrien. Nutrien yang diabsorbsi meliputi karbohidrat, protein, lemak, vitamin dan mineral. Vahdatpour et al. (2008) menyatakan bahwa peningkatan berat lemak abdominal akan memacu kerja hati lebih keras untuk metabolisme lemak, sehingga akan menurunkan berat hati. Kandungan serat kasar yang tinggi menyebabkan aktivitas hati lebih keras. Hati berfungsi mensekresikan getah empedu yang membantu absorpsi lemak (Yuwanta, 2004). Semakin tinggi level penggunaan DDGS, kandungan serat kasar juga semakin tinggi. Serat kasar pada pakan ayam broiler akan mengikat garam empedu, sehingga akan mempengaruhi pencernaan lemak (Rizal, 2006). Akibat dari kerja hati tersebut, berat hati yang dihasilkan lebih rendah pada perlakuan pakan dengan kandungan DDGS yang tinggi. Penggunaan DDGS tidak memberikan pengaruh yang nyata terhadap persentase hati. Persentase hati disajikan pada Tabel 6.

Persentase hati tidak berbeda secara nyata dengan pemberian DDGS hingga level $50 \%$. Persentase hati dipengaruhi oleh berat hati dan berat potongnya. Hati yang diperoleh dari hasil penelitian termasuk dalam keadaan sehat. Semua organ hati yang diamati tidak ditemukan adanya kelainan. Kelainan yang biasanya ditemui pada organ hati antara lain pembesaran hati, pemucatan warna ataupun adanya bintik-bintik putih (Wahyurinaningsih, 2001).

\section{Kesimpulan dan Saran}

\section{Kesimpulan}

Pemberian DDGS dalam pakan sebanyak $30 \%$ dapat mempertahankan berat dan persentase karkas, serta berat hati ayam broiler. Pada level DDGS $40 \%$ dapat menurunkan karkas yang diikuti dengan penurunan berat dan persentase lemak abdominal, serta berat hati ayam broiler yang dipelihara selama 35 hari.

\section{Saran}

Pemberian DDGS dapat digunakan sebagai bahan pakan alternatif bagi peternak ayam broiler sebagai sumber energi dan sumber protein dengan menambahkan asam amino sintetis dalam campuran pakannya. Penelitian lebih lanjut mengenai penggunaan DDGS masih diperlukan disertai dengan penambahan asam amino dalam pakan.

\section{Daftar Pustaka}

Abun. 2006. Protein dan Asam Amino pada Unggas. Jurusan Nutrisi dan Makanan Ternak. Fakultas Peternakan. Universitas Padjajaran. Bandung.

Tabel 6. Hati ayam broiler yang diberi DDGS umur 35 hari (liver of broiler which were fed with DDGS at 35 days of age)

\begin{tabular}{ccc}
\hline \hline Perlakuan (treatment) & Berat hati $(\mathrm{g})$ (liver weight $(\mathrm{g}))$ & Persentase hati $(\%)(\text { liver percentage }(\%))^{\mathrm{ns}}$ \\
\hline R 0 & $22,20 \pm 2,94^{\mathrm{b}}$ & $2,20 \pm 0,37$ \\
R 20 & $21,80 \pm 3,96^{\mathrm{b}}$ & $2,22 \pm 0,47$ \\
R 30 & $20,60 \pm 0,89^{\mathrm{b}}$ & $2,24 \pm 0,37$ \\
R 40 & $15,80 \pm 2,77^{\mathrm{a}}$ & $2,18 \pm 0,52$ \\
R 50 & $15,80 \pm 1,92^{\mathrm{a}}$ & $2,23 \pm 0,14$
\end{tabular}

a,b Superskrip yang berbeda pada kolom yang sama menunjukkan perbedaan yang nyata $(\mathrm{P}<0,05)$ (different superscripts at the same column indicate significant differences $(P<0.05))$.

ns non significant. 
Akiba, Y. 1992. Carcass and yield of edible meat as influenced by allocation and by feeding medium chain triglycerides in broiler. Proc. Netherlands. 3: 133-137.

Anggorodi, H.R. 1995. Nutrisi Aneka Ternak Unggas. PT Gramedia Pustaka Utama. Jakarta.

Anonimus. 2008. Krisis energi baru: pangan, pakan atau bahan bakar. Buletin Charoen Pokphand Edisi Februari 2008. No. 98/Tahun IX.

Baker, D.H dan Y. Han. 1993. Level amino acid profile for chick during the first three weeks post hatching. Poult. Sci. 72: 701-708.

Hartadi, H., S. Reksohadiprojo, dan A.D. Tillman. 2005. Tabel Komposisi Pakan untuk Indonesia. Gadjah Mada University Press, Yogyakarta.

Indarsih, B. 2009. Response of two different strains of commercial broilers to different dietary amino acid allowance. Media Peternakan 32(2): 104-111.

Juju, W. 2004. Ilmu Nutrisi Unggas edisi ke-5. Gadjah Mada University Press. Yogyakarta.

Leclercq, B. 1998. Specific effects of lysine on broiler production: comparison with threonine and valine. INRA, Station de Researches Avicoles, France. J. Poult. Sci. 77: 118-123.

Mahfudz, L.D. 2006. The effect of oncomfermented tofu by-product in the dirt of protein utilization of male tegal duck. J. Ind. Trop. Anim. Agric. 31(2): 129-134.

Lumpkins, B.S. and A.B. Batal. 2005. The bioavailability of lysine and phosphorus in distillers dried grains with solubles. J. Poult. Sci. 84: 581-586.

Noll, S., C. Abe, and J. Brannon. 2003. Nutrient composition of corn distillers dried grains with solubles. J. Poult. Sci. 82 (Supplement): 71.

NRC. 1994. Nutrient Requirement of Poultry $8^{\text {th }}$ ed. National Academy Press. Washington DC.

Razeai, M., H. Nassiri, M., J. Pour, R., and H. Kermanshahi. 2004. The effect of dietary protein and lysine levels on broiler performance, carcass characteristics and $\mathrm{N}$ excretion. J. Poult. Sci. 3(2): 148-152.

Rizal, Y. 2006. Ilmu Nutrisi Unggas. Andalas University Press. Padang.

Setiawan, I. dan E. Sujana. 2009. Bobot akhir, persentase karkas dan lemak abdominal ayam broiler yang dipanen pada umur yang berbeda. Seminar Nasional Fakultas Peternakan Universitas Padjajaran. Bandung.
Shanin, K.A. and A.E. Azeem, F. 2006. Effects of breed, sex and diet and their interactions on fat deposition and partitioning among depots of broiler chickens. Arch. Tierz. Dummerstorf 49(2): 181-193.

Sitompul, S. 2004. Analisis asam amino dalam tepung ikan dan bungkil kedelai. Buletin Teknik Pertanian 9(1): 118-130.

Soeparno. 2005. Ilmu dan Teknologi Daging. Gadjah Mada University Press. Yogyakarta.

Sulastri, S.M. 2003. Pengaruh kandungan lisin dan energi termetabolis berbeda dalam ransum yang mengandung ubikayu fermentasi terhadap lemak ayam broiler. Tesis Program Pasca Sarjana Fakultas Peternakan. Universitas Diponegoro. Semarang.

Tangendjaja, B. 2007. Inovasi Teknologi Pakan Menuju Kemandirian Usaha Ternak Unggas. Balai Penelitian Ternak. Bogor.

USDA. 2009. U.S. Department of Agriculture, feed grains database and electronic database. 2009. U.S. Corn Production and Use for Fuel Ethanol 1980-2009. Available at www.ers. usda.gov/Data/Feed-Grains. Accession date: $15^{\text {th }}$ February 2011.

Vahdatpour, T., N.A. Kambiz, E.N. Yahya, M.S. Naser, and V. Sina. 2008. The effects of energi increasing and protein lowering by addition of fats to diet on broiler chickens: performance and serum lipids. Asian J. Anim. Vet. Adv. 3(5): 286-292.

Wahyurinaningsih, S. 2001. Persentase berat karkas, organ dalam dan lemak abdominal ayam broiler yang diberi zinc batitracin, probiotik bacillus $s p$ dan Saccharomyces cerevisiae dalam ransumnya. Skripsi. Institut Pertanian Bogor. Bogor.

Wang, Z., S. Cerrate, C. Coto, F. Yan, F.P. Costa, A.A. Maksoud, and P.W. Waldroup. 2008. Evaluation of corn distillers dried grains with soluble in broiler diets formulated to be isocaloric at industri energi levels or formulated to optimum density with constant $1 \%$ fat. Int. J. Poult. Sci. 7(7): 630-637.

Wang, Z., S. Cerrate, C. Coto, F. Yan, and P.W. Waldroup. 2007. Utilization of distillers dried grains with solubles (DDGS) in broiler diets using a standardized nurtien matrix. Int. J. Poult. Sci. 6(7): 470-477.

Yuwanta, T. 2004. Dasar Ternak Unggas. Kanisius. Yogyakarta.

Zuprizal dan M. Kamal. 2005. Nutrisi dan Pakan Unggas. Fakultas Peternakan. Universitas Gadjah Mada. Yogyakarta. 